\title{
Dronekrigeren og krigen på skærmen
}

Fra de allertidligste kilder, som den forhistoriske arkæologi samt hule- og vasemalerier fremstiller, ved vi, at mennesket altid har betjent sig af våben til såvel jagt som krigsførelse. Den militære orientering tilkendegiver sig endvidere $\mathrm{i}$ forhistoriens inddeling $\mathrm{i}$ sten-, bronze- og jernalder, der hovedsageligt er defineret ud fra våbnenes materielle beskaffenhed. Også den helt tidlige litteratur opviser omhyggelige beskrivelser af krig, soldater og våben. Særlig prægnant i Homers berømte krigsdigt Iliaden. Hvad der står klart i disse tidlige kilder er, at krigens historie næppe kan adskilles fra våbenteknologiens historie; historierne hører sammen, ligesom de også mere generelt hører sammen med menneskets historie.

I en bog om netop krig og teknologi skriver krigshistorikeren Martin van Creveld, at "krigen er gennemtrængt af teknologi i en grad, hvor ethvert element er styret af eller i det mindste påvirket af teknologi” og videre, at hele vores måde at tænke og forstå krigen er påvirket af teknologi (Creveld 1989: 311). Dersom dette er tilfældet, må man følgelig undre sig over, hvorfor teknologien spiller en så lille rolle hos Carl von Clausewitz, Sun Tzu, Antoine-Henri Jomini, Niccoló Machiavelli eller hos andre af de kanoniserede krigsfilosoffer. Noget kunne måske tyde på, at teknologien er blevet betragtet som noget sekundært overfor krigens primære idé, som krigsfilosofien på forskellig vis fremstiller. Omvendt har mange nyere krigsteoretikere og politikere efter Golfkrigen anvendt begrebet Revolution in Military Affairs (RMA) og dermed betonet teknologien som en altafgørende og revolutionerende faktor for krigens udvikling og afgørelse (Hansen 2005: 35). Især efter den vestlige højteknologiske krigsmaskines modgang i Irak- og Afghanistankrigene, er der delte meninger om denne deterministiske prioritering af teknologien (Møller 2002; Peters 2005).

I det følgende vil jeg vise, hvordan den krigsteknologi, der i dag er kendt som droner eller dronefly, ${ }^{1}$ udfordrer den ovenfor beskrevne dikotomiske positionering, der hhv. under- og overdriver teknologiens betydning for krigen. Således vil jeg argumentere for, at droneteknologien på den ene 
side blot er seneste manifestation af en gammelkendt militær idé om strategisk udnyttelse af distance, men at dronerne på den anden side påvirker krigens metafysiske beskaffenhed derved at især krigens rumlige forhold ændres, hvilket bl.a. viser sig i beskrivelser af dronekrig som risikofri krig og dydlos krig. Efter et kort rids af dronernes anvendelse og deres tekniske specifikationer, beskrives dronerne og den deraf følgende skarmkrig i lyset af globaliseringens idéhorisont og især med dennes brud med en traditionel geografisk forståelse af rummet. Dette sættes i forhold til Clausewitz' krigsfænomenologi, der omvendt viser, at den strategiske udnyttelse af afstand er et grundvilkår snarere end et egentligt nybrud i krigsførelsen, ligesom også Clausewitz' beskrivelser af krigerånden anvendes som afsæt til at diskutere og tilnærme en antropologi om dronepiloten. På baggrund af disse undersøgelser diskuterer sidste del af artiklen, hvordan dronerne har ændret forholdet, eller positionen, mellem soldat/pilot og slagmark. Til beskrivelsen af dette ændrede forhold foreslås og udvikles et begreb om den pä-skarmen-varende krig inspireret af Martin Heideggers forholdsordstyrede tænkning i Sein und Zeit (Væren og tid).

Tilsammen bidrager disse forskellige perspektiver til at begrebsliggøre og forstå, hvad der, på trods af vores egen vante omgang med informationsteknologier og mediernes tiltagende dækning af droneangreb, stadig forekommer nærmest ubegribeligt; ja, nærmest science fiction-agtigt: At krige i dag kan udkæmpes på skærme af særlige dronekrigere, der befinder sig mange tusinde kilometer fra de slagmarker, hvori de intervenerer.

\section{Hvad er en drone?}

I 2011 udgav det britiske forsvarsministerium en rapport, der for første gang omfattende diskuterer droners fremtidige rolle i Storbritanniens forsvarspolitik. I rapportens indledning gives en kort og formel definition af en drone:

Et ubemandet fly [en drone] er defineret som et luftfartøj uden menneskelig operatør, er fjernstyret med varierende grad af automatiserede funktioner, kommer normalt tilbage og kan opbevare dødelig eller ikke-dødelig last (Ministry of Defence 2011: 1-2).

Udover en definition giver rapportens eksistens også et vink om, at dronen er en teknologi, der har indtaget en central plads i forsvars- og sikkerhedspolitiske overvejelser. ${ }^{2}$ 
Selvom dronerne først $\mathrm{i}$ den seneste tid er blevet almenkendte $\mathrm{i}$ offentligheden, er de teknologiske aspirationer frem mod nutidens modeller dog en hel del ældre. Således kan idéen om droner siges at være vokset ud af en kombination af krigsfly og fjernbetjente krydsermissiler, som begge indtog slagmarken i 1 . verdenskrig. Igennem det 20. århundredes mange efterfølgende væbnede konflikter er disse to teknologier på forskellig vis smeltet mere og mere sammen og i dag findes dronerne i mange varianter og er med typisk krigspatos tildelt navne såsom Predator, Raven, Reaper, Hunter og Global Hawk. ${ }^{3}$ Hvad der først og fremmest adskiller en drone fra et almindeligt jagerfly er, at den fjernstyres via satellitkommunikation af piloter placeret et helt andet sted end der, hvor flyet er på mission. En typisk konstellation er således følgende: Dronen flyver ud fra baser i eller nær Pakistan, men navigeres ca. $12.000 \mathrm{~km}$ derfra i Nevada-ørkenen af dronepiloter placeret $\mathrm{i}$ dertil indrettede kontrolrum.

For at begrænse de tekniske detaljer fokuseres her på den meget anvendte amerikanske Predator-drone, som debuterede i krigen i det tidligere Jugoslavien i midten af 1990erne (Singer 2009: 58). ${ }^{4}$ Efter terrorangrebet på World Trade Center og Pentagon i 2001 blev Predator-dronen, der hidtil udelukkende var anvendt til rekognosceringsmissioner, udstyret med Hellfire-missiler under vingerne. En af årsagerne var, at Predator-droner flere gange før terrorangrebet havde identificeret Osama bin Laden i Afghanistan, men uden nogen mulighed for at angribe ham (Singer 2009: 34). Men i dag kan flere af de amerikanske droner, deriblandt Predatordronen, altså angribe. Til eksempel var der i 2011 i alt 70 droneangreb i Pakistan, næsten alle sammen (97\%) i det føderale stammeområde Waziristan, der arealmæssigt er ca. dobbelt så stort som Sjælland (New America Foundation 2012). Det er især efter, at dronerne er begyndt at angribe, at de har fanget mediernes interesse (jf. også note 2), hvilket kan skyldes, at selve overvågningsaspektet nærmest er usynligt og primært af militær interesse, mens angrebsaspektet giver dronerne et output, der er ganske synligt og kontroversielt.

Udover Hellfire-missilerne er Predator-dronen udstyret med to forskellige kameraer, der fungerer som flyets syn; det ene kan se om dagen, det andet, som er infrarødt, om natten. Kameraerne har en så høj opløsning, at de fra en højde på omkring tre kilometer kan identificere nummerpladen på en bil og fra lavere højder også bestemme våbentyper (Singer 2009: 222). Derudover har Predator-dronen også en laser, der via GPS kan udpege de mål, som kameraerne opfanger, blandt andet til efterfølgende 
brug for bemandede bombefly og som sigtekorn for egne Hellfire-missiler. De to piloter i kontrolrummet styrer dronen via et interface af joysticks, tastatur og skærme. Skærmene giver dem adgang til den information, som kameraerne og GPS-systemet indhenter, og via joysticks og tastatur kan de styre flyet, affyre missiler etc.; alle in- og outputs foregår i realtid (Singer 2009: 222). På trods af enorme afstande er dronepiloterne bag skærmene i Nevada-ørkenen altså ikke blot i stand til på nært hold at overvåge fjender overalt i verden, men også til at intervenere direkte i krigen ved f.eks. at dræbe fjender eller ødelægge bygninger og andet materiel. Dette paradoksale forhold mellem nær og fjern er helt væsentligt for forståelsen af dronekrig og vil i løbet af artiklen blive udfoldet og begrebsliggjort.

\section{At drage i krig...på skærmen}

At drage i krig på skarmen og dermed opløse geografiske skel, som ellers altid har været af militærstrategisk interesse, synes at udfordre den gængse forståelse af, hvad krig er. I sin bog om globalisering kredser Zygmunt Bauman, med reference til Paul Virilio, netop om geografiens endeligt i senmodernitetens højhastighedsverden:

Afstandene betyder ikke længere noget, efterhånden som ideen om en geofysisk grænse bliver stadig vanskeligere at opretholde i "den virkelige verden". Det står pludseligt klart, at opdelingen i kontinenter og af kloden som helhed har været resultatet af afstande, som engang var overvældende virkelige på grund af de primitive transportmidler og rejselivets strabadser (Bauman 1999: 18).

Ikke kun hurtigere biler, tog og fly har i dag erstattet de primitive transportmidler, som Bauman taler om. Også informationsteknologien, og måske især den, har bidraget til udviskningen af afstande ved at gøre kommunikation mere uafhængig af rum (Bauman 1999: 20). Ifølge Bauman medfører dette, at rummet - og tiden, kunne man tilføje - er blevet " [...] frigjort fra den menneskelige krops begrænsninger” (Bauman 1999: 23).

Krigen, som den udspiller sig på dronepiloternes skærme, inkarnerer denne idé om globaliseringens frigørelse af tiden og rummet fra kroppen og aktualiserer derved den berømte kartesianske dualismes adskillelse af krop og sjæl. Mest prægnant viser denne frigørelse sig ved, at de beskrevne satellittransmitterede informationer, som over store afstande $i$ realtid forbinder drone og pilot, på samme tid også adskiller dem. Ligesom 
Descartes’ subjekt bliver et verdensløst og kropsløst subjekt, bliver piloten adskilt fra dronen og vigtigere endnu fra slagmarkens fysiske nærvær og risici. Hidtil har militærtjenesten indebåret, at soldaten har måttet forlade sit land og sin familie med risiko for aldrig at vende tilbage, men med dronerne ændres dette forhold radikalt; udtrykket 'at drage i krig' får en helt ny betydning (Wall \& Monahan 2011: 246). Overvej blot forskellen på dronepiloten, der efter endt arbejdsdag på mission i Pakistan kan tage hjem og spise aftensmad med sin familie i Nevada overfor Odysseus, der må drage til Troja for at deltage i den ti år lange krig og efterfølgende bruge tyve turbulente år, før han igen kan vende hjem til Penelope og Ithaka.

Det er måske ikke helt rimeligt at sammenligne myte og virkelighed, men det skærper dog forståelsen af det, som flere har omtalt som risikofri krig (Singer 2009). Hermed menes, at piloterne, der sidder i USA og styrer dronerne, ikke er udsat for den risiko, man normalt forbinder med at drage i krig. Det er i den forbindelse interessant at bemærke, at Carl von Clausewitz i starten af femte bog i Vom Kriege (Om krig) netop kredser om muligheden for at skabe et slags risikofrit krigsrum, hvilket indikerer at dronerne blot er en markant virkeliggørelse af en velkendt strategisk idé om udnyttelse af distance:

Beskyttelsen kan bestå i fæstninger eller i store naturlige hindringer, men også $\mathrm{i}$ at der er betydelig afstand til det øvrige krigsrum, - En sådan del af krigsrummet er ikke blot et stykke af helheden, men selv en lille helhed, der derved mere eller mindre er i den situation, at de forandringer, der sker $\mathrm{i}$ det øvrige krigsrum, ikke har direkte, men kun indirekte indvirkning på den (Clausewitz 1986: 308).

Denne snart 200 år gamle beskrivelse af et rum i krigen, hvori krigen kun indirekte virker, er vel nærmest den mest præcise definition på dronepiloternes risikofrie kontrolrum. Senere i artiklen skal jeg, med inspiration fra Heideggers vokabular, forsøge at konceptualisere dronepiloternes krigsrum på skærmen som et slags mellemrum mellem slagmark og kontrolrum.

Selvom risikofri krig umiddelbart kunne synes attraktiv, advarer den tidligere nævnte rapport fra det britiske forsvarsministerium om, at den risikofrie krig kan medføre, at det bliver lettere for såvel befolkningen som politikerne at vælge krigen frem for diplomatiet som løsning på konflikter (Ministry of Defence 2011: 5-9). De to fremtrædende krigsteoretikere James Der Derian og Christopher Coker deler ligeledes denne bekymring (Singer 2009: 325 ; Coker 2001: 150). 


\section{Krigerånden - fra skyttegraven til skærmen}

Et andet spørgsmål, der rejser sig, er, hvordan dronernes risikofrie krig ændrer det, som Clausewitz kalder Krigerånden (Clausewitz 1986: 66). Som navnet antyder, udforsker Clausewitz i kapitlet, hvilke psykiske karakteristika der kendetegner krigeren. Hans beskrivelser af mod, beslutsombed, are, standhaftighed, stedsans etc. udvikler sig nærmest som en hel antropologi om krigeren. Men er denne antropologi også dækkende for dronekrigeren? Svaret er tvetydigt. På den ene side mener piloten Brian Burridge, der havde det overordnede ansvar for de britiske tropper ved invasionen i Irak i 2003, at den skærmkrig, som dronepiloterne udkæmper, er en dydlos krig, ${ }^{6}$ netop fordi piloten ikke har nogen følelsesmæssig forbindelse til slagmarken (Singer 2009: 333). Men på den anden side fastsætter den britiske krigshistoriker John Keegan udspringet til den tendens, som Burridge altså kalder dydløs krig, langt tidligere. Via tre historiske nedslag - slaget ved Agincourt i 1415, slaget ved Waterloo i 1815 og slaget ved Somme i $1916^{7}$ - viser Keegan således, at soldatens forhold til både slagmark og fjende bliver mere og mere upersonligt og distanceret i takt med den teknologiske forbedring af våben og den samtidige geografiske udvidelse af slagmarken (Keegan 1978: 265; 320f.). Selvom der synes lang fra skyttegravskrigen i Somme til skærmkrigen i det nordlige Pakistan (eller er det i Nevada?), kan trækket af en dydløs og upersonlig krigsførelse siges at være videreført. Blot synes den $12.000 \mathrm{~km}$ lange afstand mellem pilot og slagmark at understrege Keegans pointe.

Som man kunne forvente, har især medierne også sammenlignet dronepiloternes skærmkrig med computerspil og dermed betvivlet dronepiloternes evne til at skelne det virkelige fra det virtuelle (Shachtman 2005; Ahmad 2011; Ali 2010). En sådan kritik potenseres når dronepiloter beskriver deres oplevelser af at flyve en drone som: "It's like a video game, the ability to kill. It's like [...] freaking cool" (Singer 2009: 395), eller: "The only thing missing is the popcorn"8 (Spinetta 2009: 23). Når man dertil tilføjer resultater fra psykologiske studier (Grossman 1995: 97ff.), der viser, at vanskeligheden ved at slå ihjel aftager i takt med, at distancen til fjenden forøges, potenseres kritikken yderligere. Hermed tilføjes også et psykologisk perspektiv til Baumans idé om teknologiens opløsning af afstand og dermed af rummets frigørelse fra kroppen; afstand bliver psyko-spatisk derved, at fysisk afstand også har med psykisk distancerethed at gøre.

På trods af den fysiske afstands tilknytning til psykisk distance findes 
der dog andre antagelser, der udfordrer denne tese. Eksempelvis viser en række psykologiske studier, at dronepiloter i lighed med almindelige piloter er udbrændte, lider af kronisk træthed, generel følelsesmæssig udmattelse og endda også af posttraumatisk stresssyndrom (Tvaryanas \& Thompson 2006; Tvaryanas \& MacPherson 2009; Chapelle, McDonald \& McMillan 2011). Årsagerne til dette ret overraskende resultat er imidlertid uklare, men et bud kunne være, at imens den udstationerede pilots krigshandlinger legitimeres i kraft af, at pilotens eget liv er i fare, giver dronepiloternes risikofrie skærmkrig ikke denne moralske tilladelse til at slå ihjel. Man kan desuden argumentere for, at ethvert trin i våbenteknologiens udvikling indebærer en forøgelse af våbnenes potentielle rækkevidde og følgelig en forøgelse af afstanden til fjenden (Singer 2009: 396). Geografisk betragtet bekræfter dronen måske nok dette argument, men grundet kvaliteten af droneflyets kameraer er dronepilotens fjende faktisk mere synlig end fjenden er det for piloten $i$ et almindeligt bombefly eller for en operatør, der affyrer krydsermissiler. På den ene side er slagmarkens rædsler altså bemærkelsesværdigt livagtige, og på den anden side nærmest usandsynligt langt borte.

Et sted i kapitlet om krigerånden, skriver Clausewitz:

Det hjerteskærende syn af farer og lidelser lader følelsen få overvægt over forstandens overbevisning, og i det skumrings lys, som indhyller alle fænomener, er en dyb, klar indsigt så vanskelig, at ændring af synspunkter bliver mere forståelig og tilgivelig (Clausewitz 1986: 79).

Om dronepiloternes oplevelser af (skærm)krigens farer og lidelser også tildeles en sådan forstående amnesti er vanskeligt at vurdere, ligesom det heller ikke er lige til at afgøre, i hvor høj grad dronerne ændrer krigens natur, eller om de blot iklæder den en ny futuristisk haute couture. I stedet for at forsøge at afgøre denne problematik vil jeg i det følgende afsnit forsøge at skabe en forståelse af den krig, som udkæmpes på dronepiloternes skærme, som en sarlig form for krig. Prædikatet sarlig betyder nemlig langt fra det samme som revolutionerende. Blot skal det særlige her markere, at dronepiloterne er i et særligt forhold til krigen. Hvad jeg vil gøre, er at forsøge at begrebsliggøre denne krigsform ved at tilføje en enkelt lille præposition - et $p \dot{a}$ - til Heideggers forholdsordstyrede vokabular i Sein und Zeit, hvorved det lader sig gøre at skabe en forståelse af dronekrig som en på-skarmen-varende krig. 


\section{Den på-skærmen-værende krigs fjernelse af verden}

Som just antydet giver sproget et vink om, at noget har ændret sig med dronepiloternes skærmkrig. I forlængelse af det forrige drejer det sig om paradokserne virkelig/virtuel, nær/fjern og revolutionerende/gammelkendt, og viser sig i det usikre valg af adækvate præpositioner til beskrivelsen af forholdene mellem dronepiloten, droneflyet, slagmarken og fjenden: Er dronepiloten i krig $i$ Afghanistan? Er han på slagmarken svævende over fjenden? Er dronen $i$ Pakistan eller ved pilotens handlende hænder? Hver gang et sådant forhold skal beskrives i forbindelse med dronerne, synes valget af den hensigtsmæssige præposition at efterfølges af en overvejelse af, om ikke den valgte præposition burde omgives af anførselstegn, kursiveres eller på anden vis markeres som tvetydig.

Med en vis ret kunne man kalde Martin Heidegger for prapositionernes filosof. Ingen anden tænkers begrebsapparat er præget af så mange præpositioner, som det er tilfældet hos Heidegger. Især i Sein und Zeits forsøg på at begribe menneskets forhold til sig selv, verden, (brugs)tingene og naturen introduceres disse mere eller mindre mærkelige forholdsordsstyrede neologismer som f.eks. det forbaindenvarende, det vedhandenvarende, iverden-varen, omverdensligheden, tilstedevaren etc. ${ }^{9}$ Heideggers vokabular kan derfor anvendes som et analytisk greb til at tilnærme en forståelse af de forhold, der udspiller sig mellem dronepiloter (mennesker), droner (ting) og slagmark (verden).

Mennesket er i-verden-varen, skriver Heidegger. Defineret negativt vil det sige, at mennesket ikke er $i$ verden, ligesom eksempelvis noget vand er $i$ en kop, ligesom dronepiloten heller ikke er $i$ verden blot fordi han er i et kontrolrum i Nevada. (Heidegger 2007: 75). Snarere vil i-verden-varen ifølge Heidegger sige, at vi altid allerede opholder os ved verden, dybt optaget af dens ting og anliggender (Heidegger 2007: 76). Dette betyder, at verden er brugbar for mennesket, og at det er gennem vores brug af de vedhåndenværende ting, at vi forstår os på verden. Det er dog egentlig ikke tingene, som vi er rettet mod, men snarere de varker som vi fremstiller med hjælp fra tingene (Heidegger 2007: 92). Det, som dronepiloten opholder sig ved og varetager, altså hans vark, er således krigen på skærmen. Dette skaber et i første omgang kryptisk blandingsforhold, derved at dronepiloternes i-verden-væren blandes med en på-skarmen-varen, altså ikke en væren $i \mathrm{Ne}$ vada eller $i$ Pakistan, men slet og ret en væren på skærmen. Denne påskærmen-væren kan tilnærmes yderligere ved at beskrive den proces, som 
Heidegger kalder fjernelse af fjernhed:

Fjernelse vil sige at få det fjerne, dvs. fjernheden af noget, til at forsvinde, altså tilnærmelse [...] Alle former for hastighedsforøgelse, som vi i dag mere eller mindre nødtvunget går med på, higer efter at overvinde fjernheden. Med "radiofonien" eksempelvis fuldbyrder tilstedeværen [mennesket] i dag noget, som det i sin tilstedeværensmening endnu ikke er muligt at overskue, nemlig fjernelsen af 'verden' via udvidelsen af den dagligdags omverden [...] Det efter sigende "nærmeste" er slet ikke det, som har den mindste afstand "fra os". For den, der eksempelvis bærer briller, som afstandsmæssigt er så tæt, at de sidder "lige på næsen", er dette ibrugtagne brugstøj omverdensligt længere borte, end billedet på væggen, som befinder sig overfor (Heidegger 2007: 130-131).

Ligesom Heideggers eksempel, radiofonien, fjerner dronerne også 'verden', i den forstand, at krigen så at sige tranger ind i dronepiloternes kontrolrum, hvorfra den ikke blot kan beskues, men også, især pga. muligheden for navigation i realtid, direkte varetages. Således modsvares Heideggers brilleeksempel i det ovenstående citat altså af dronepiloternes interface; det er ikke interfacet der er nærværende, men derimod krigsvarket på skærmen. Denne pointe udfordrer opfattelsen af dronekrig som en langdistancekrig. Geografisk betragtet er dronekrigen da også uomtvisteligt en sådan, men med Heidegger bliver afstandsbedømmelsen fravristet sit naturvidenskabelige udgangspunkt, og det bliver muligt at betragte dronekrigen som en ganske nærværende form for krig. Dette kan også være en del af forklaring på, hvorfor dronepiloterne er ramt af mange af de samme psykiske symptomer som de udstationerede soldater og piloter. I hvert fald synes opfattelsen af dronekrig, som en risikofri krigsform, at hvile på en naturvidenskabelig forståelse af afstand, der ikke har øje for de psykiske risici i nærværet på dronepiloternes skærme.

Noget er dog radikalt anderledes med dronernes fjernelse af fjernhed $\mathrm{i}$ forhold til Heideggers eksempler. Selvom radioen, og det samme gælder i øvrigt fjernsynet, udvider verden, er det en passiv udvidelse; radioen og fjernsynet bringer så at sige verden ind i stuerne, men uden samtidigt at give mulighed for at varetage den. I en heideggersk optik kan radioen og fjernsynets fremstilling af eksempelvis krig således fint betragtes som et krigs-værk, men det er et urørligt og lukket værk, som radioen og fjernsynet præsenterer for os. Med andre ord suppleres denne udvidede fjernsyns- og radioverden ikke af nogen mulighed for varetagelse. Dronetek- 
nologien derimod tilbyder denne mulighed. Dronepiloternes mulighed for i realtid at reagere på krigen er altså det, der åbner krigs-værket for varetagelse. Modsat fjernsynsskærmens repræsentation af krig er krigen således vitterligt på dronepiloternes skærme, netop fordi de kan varetage den. Imens fjernsynsskærmen erstatter et faktisk fravær med et simuleret nærvær, erstatter dronepiloternes skærme altså et faktisk fravær med et faktisk nærvær. Inspireret af Heidegger kan man derfor sige, at dronekrigen er på-skarmen-varende. Dermed introduceres præpositionen $p a ̊-d e r$ ikke er repræsenteret i Heideggers vokabular - til beskrivelsen af menneskets forskellige forhold til det værende. Behovet for en sådan begrebsudvidelse vokser i takt med, at krig, samt en række andre fænomener, i stigende grad bliver på-skærmen-værende derved, at de kan varetages, og ikke blot iagttages, på skærme.

Det er vigtigt at slå fast, at denne nye forholdsmåde netop udmærker sig ved at være tosidig. Det er ikke kun krigen, der er på skærmen, ligesom i fjernsynets krigsreportager, dronepiloten er også på skærmen med mulighed for aktivt at varetage krigs-værket. Men ligeså vigtigt er det at lade begrebet om det på-skærmen-værende implicere en distinktion mellem at være $p a ̊-$ skarmen og i-verden. Således afgrænser skærmen et specifikt krigsrum ${ }^{10}$ eller en særlig verden, hvor dronepiloterne kan varetage krigsværket (overvåge og angribe fjender), og det er netop denne skarmverden, som begrebet om det på-skærmen-værende beskriver. Hermed etableres en forståelse af skærmen som et sted og ikke blot et medie, hvor krigen udspiller sig på en særlig måde, dvs. efter et særligt regelsæt bestående af de muligheder og begrænsninger som droneteknologien skaber. Skærmverdenen adskiller sig fra den verden, som den udstationerede soldat eller pilot befinder sig i, ved f.eks. at være fri for fysiske risici, men den er ikke mere virkelig end denne verden, ligesom f.eks. fodgængerens verden heller ikke er mere virkelig end bilistens, blot anderledes. Ved at antyde et slags mellemrum mellem dronepiloternes kontrolrum og slagmarkens krigsrum beskriver og indfanger begrebet om det på-skærmen-værende det paradoks, der som et ledemotiv er dukket op i nærværende artikel i forskellige variationer: Dronerne, der på én gang skaber en helt ny krigsform og samtidig blot er seneste manifestation af en velkendt strategisk ide om at skabe særlige krigsrum uden direkte forbindelse til slagmarken. Eller i en anden variation: Dronepiloterne, der på én gang med hjælp fra avanceret teknologi er ganske tæt på krigen og samtidig meget langt fra dens umiddelbare farer. 


\section{Afsluttende bemærkninger}

Heidegger skrev, at vi med radioen var i fuld gang med at fuldbyrde en fjernelse af verden, og at vi endnu ikke kunne overskue konsekvenserne af denne proces. De satellitsignaler, som dronerne styres af, er blot en videreudvikling af de radiosignaler som har inspireret Heideggers radioeksempel, og som kort før udgivelsen af Sein und Zeit i 1927 blev anvendt som kommunikationsredskab i 1 . verdenskrig. Men overskueligheden synes ikke at være blevet mindre $\mathrm{i}$ takt med at satellit- og internetkommunikation har gjort verden endnu mindre. Så meget mere synes det vigtigt at forfølge det krav om et nyt sprog, som krigsteoretikeren James Der Derian i en artikel fra 1999, altså for dronerne blev alment kendte, stiller til forskningen. Der Derian argumenterer for, at introduktionen af computere, videoskærme og realtidskommunikation i krigen har ændret krigsførelsen mere end nogen anden teknologi, men at denne ændring kræver et nyt sprog, som militærlitteraturen endnu ikke har formået at udvikle (Der Derian 1999: 90). I håbet om at nedbringe den uoverskuelighed, der stadig kendetegner emnet, kan nærværende artikels diskuterende begrebsudvikling opsummeres som et eksperimenterende og præliminært bidrag til et sådant nyt sprog.

\section{Noter}

1 Det vil sige fjernstyrede ubemandede fly. På engelsk: Drone eller Unmanned Aeiral Vebicle (UAV).

2 Tre forskellige statiske nedslag med udgangspunkt i hhv. militær, ofre og medier giver yderligere en fornemmelse af det øgede fokus på droner. Militar: Siden 2001 er det amerikanske forsvars investeringer i droner vokset med ca. 23\% per år (Singer 2009: 61). Ofre: I det nordlige Pakistan er antallet af dødsofre ved droneangreb steget regelmæssigt fra 273 i 2008, 570 i 2009 og 909 i 2010 (Pegg 2011). Medier. En søgning på ordet dronefy i den danske avisdatabase Infomedia viser, at ordet først indgår i danske avisartikler fra 2008 og dertil, at der i 2009 i alt findes 51 artikler, der indeholder ordet og 328 i 2010. Den stigende tendens er den samme, hvis søgeordet erstattes med det $\mathrm{i}$ en søgemaskine noget mere usikre homonym drone.

3 Selvom disse varianter alle er amerikanske, er der, foruden Storbritannien og USA, også en lang række andre lande der udvikler og investerer i droner, deriblandt Iran, hvis Misrad-drone Hezbollah anvendte til angrebet mod Israel i 2006 (Singer 2009: 264). 
4 En del referencer i det følgende refererer til Peter Warren Singers bog Wired for War (2009), der er den første bog, der systematisk har behandlet droner.

5 Fra et interview med James Der Derian af Peter Warren Singer.

6 Engelsk: virtueless war.

7 Alle slag er blandt de vigtigste slag i hhv. Hundredårskrigen (1337-1453), Napoleonskrigene (1804-1815) og 1. verdenskrig (1914-1918).

8 Dansk: "Det er ligesom et computerspil, evnen til at dræbe. Det er ligesom [...] helt vildt sejt" og "Det eneste der mangler er popcornene".

9 Begreberne bringes her og i det følgende i overensstemmelse med Christian Rud Skovgaards danske oversættelse af Sein und Zeit (Heidegger 2007).

10 jf. her også Clausewitz’ tidligere omtalte beskrivelser af et særligt afgrænset krigsrum.

\section{Litteratur}

Ahmad, Muhammad Idress (2011): "The Virtue-less war of the 'Nintendo bomber"', Aljazeera.net, 28/6, http://english.aljazeera.net/indepth/opinion/2011/06/ 201162682825424222.html (tilgået 31/01/2012).

Ali, Syed Hamad (2010, 15. december): "War is not a video game - drone attacks that kill innocents can only escalate and prolong violence", openDemocrary.net, 15/12, http://www.opendemocracy.net/syed-hamad-ali/war-is-not-video-game-droneattacks-that-kill-innocents-can-only-escalate-and-prolo-0 (tilgået 31/01/2012).

Bauman, Zygmunt (1999, [1998]): Globalisering, København: Hans Reitzels Forlag.

Chapelle, Wayne, Kent McDonald \& McMillan, Katharine (2011): Important and Critical Psychological Attributes of USAF MQ-1 Predator and MQ-9 Reaper Pilots According to Subject Matter Expert, http://airforcemedicine.afms.mil/idc/groups/public/documents/afms/ctb_155782.pdf (Tilgået 31/01/2012).

Clausewitz, Carl von (1986, [1832]): Om Krig I, 1.-5. bog, København: Rhodos.

Coker, Christopher (2001): Human Warfare, London: Routledge.

Creveld, Martin van (1989): Technology and War, New York: The Free Press.

Der Derian, James (1999): "Den virtuelle krigs bemærkelsesværdige overdrivelse", Udenrigs, vol 54, nr. 1, s. 82-92.

Grossman, Dave (1995): On Killing, New York: Little, Brown \& Co.

Hansen, Jens Claus (2005): "Ny krigsførelse i informationsalderen? Om 'Revolution in Military Affairs' og Irakkrigen”, Mediekultur, vol. 38, s. 34-42.

Heidegger, Martin (2007, [1927]): Varen og tid, Århus: Klim.

Keegan, John (1978, [1976]): The Face of Battle, New York: Penguin Books.

Ministry of Defence (2011): Joint Doctrine Note 2/11. The UK Approach to Unmanned Aircraft Systems, http://www.mod.uk/NR/rdonlyres/F9335CB2-73FC-4761-A428DB7DF4BEC02C/0/20110505JDN_211_UAS_v2U.pdf (tilgået 31/01/2012). 
New America Foundation (2012): “2011 - The Year of the Drone”, http://conterterrorism.newamerica.net/drones/2011 (tilgået 31/01/2012).

Møller, Bjørn (2002): "The Revolution in Military Affairs - Myth or Reality” (Working Paper), Commonwealth Institute, http://www.comw.org/rma/fulltext/02moller.pdf , (tilgået 31/01/2012).

Pegg, David (2011): "Drone statistics visualised", Bureau of Investigative Journalism, 10/8, http://www.thebureauinvestigates.com/2011/08/10/resources-and-graphs/ (tilgået 31/01/2012).

Peters, Ralph (2005): New Glory, New York: Sentinel (Penguin Group).

Tvaryanas, Anthony \& William Thompson (2006): "Fatigue in military aviation shift workers - survey results for selected occupational groups", Aviation, Space, and Environmental Medicine, vol. 77, s. 1278-1282.

Tvaryanas, Anthony \& Glen D. MacPherson (2009): "Fatigue in Pilots of Remotely Piloted Aircraft Before and After Shift Work Adjustment", Aviation, Space, and Environmental Medicine, vol. 80, s. 454-461.

Shachtman, Noah (2005): "Drone School, a Ground's-Eye View", Wired Magazine, 27/5, http://www.wired.com/science/discoveries/news/2005/05/67655 (tilgået $31 / 01 / 2012)$.

Singer, Peter W. (2009): Wired for War, London: Penguin Books.

Spinetta, Lawrence (2009): "Predator UAV - The Ultimate Teleoperated Robot", Robot, vol. 16, s. 20-22.

Wall, Tyler \& Torin Monahan (2011): "Surveillance and violence from afar - The politics of drones and liminal security-scapes", Theoretical Criminology, vol. 15, nr. 3, s. 239-254. 
